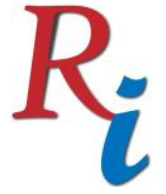

Asia Proceedings of Social Sciences

(APSS)

www.readersinsight.net/APSS

\title{
Exploring Online Apparel Shopping Satisfaction on Sizing and Fit for Malaysian Children
}

\author{
Nurashikin Saaludin* \\ Universiti Kuala Lumpur Malaysian Institute of Information Technology \\ Malaysia \\ Mohd Hafizul Ismail
}

Universiti Kuala Lumpur Malaysian Institute of Information Technology Malaysia

\section{Suriyati Harun}

Universiti Kuala Lumpur British Malaysian Institute

Malaysia

*Corrosponding author's Email: nurashikin@unikl.edu.mty

Peer-review under responsibility of $4^{\text {th }}$ Asia International Conference 2018 editorial board (http://www.utm.my/asia/our-team/) (C) 2018 Published by Readers Insight Publisher, lat 306 Savoy Residencia, Block 3 F11/1,44000 Islamabad. Pakistan, info@readersinsight.net This is an open access article under the CC BY-NC-ND license (http://creativecommons.org/licenses/by-nc-nd/4.0/). 


\section{Rese a r ch H igh I ights}

The advancement for the internet facilities have encouraged the the proliferation of online shopping especially apparel segments in Malaysia. Apparel are not only for basic neccessity but also as a trendy fashion as well. Meeting an appropriate sizing and comfortable apparel are the most important elements for consideration of purchasing. This study has determined the uncertainty problem on sizing and fit of apparel for Malaysian children from the perceptive of parents or guardians. Girth and length were identified as a good key dimensions measurement. Height and bust and, height and waist were used to measure upper body and lower body respectively. Analysis of variance (ANOVA) has proved that higher income households had greater discrepancies with respect to satisfaction levels items than lower income household. Different apparel sizing system by brands and manufacturers could lead to consumer confusion and dissatisfaction in shopping via online.

\section{Graphical A bst r a c t}

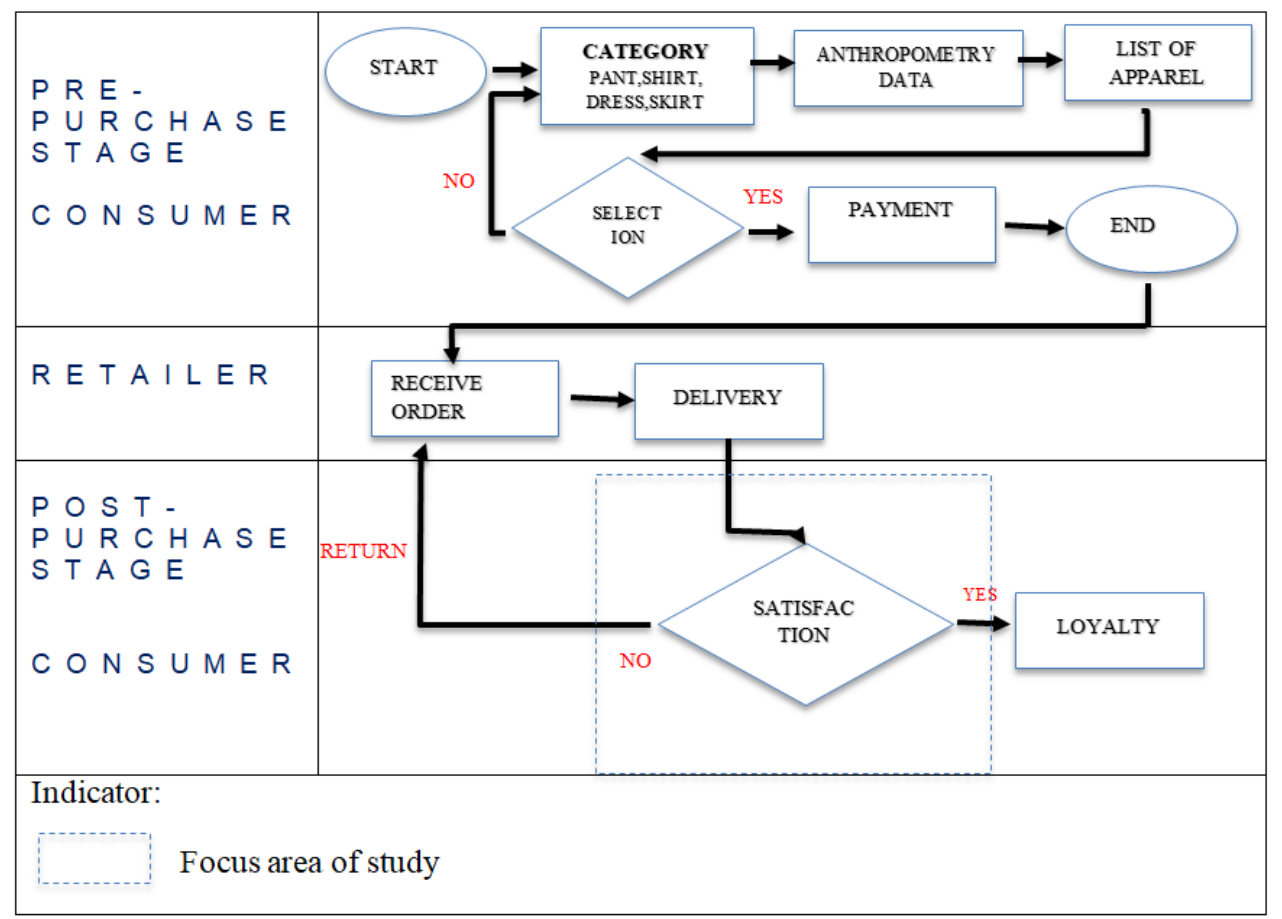

Figure1: Online Shopping System; Big Picture 


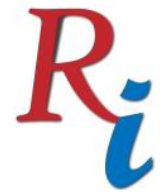

Asia Proceedings of Social Sciences

(APSS)

www.readersinsight.net/APSS

\section{Research Objectives}

Online shopping for apparel have become poised for significant growth among Malaysian consumers. As indicated by Wu \& Tseng (2014), online shopping caters the busy modern people which the world of fashion is at their fingertips. However, when consumers cannot see the physical apparel before buying via online, it will create the feeling of dissatisfaction among them. The major problem is related to sizing and fit (Zakaria, 2016; Norum, 1995)

Many studies have been done to understand the consumers satisfaction in apparel sizing and fit but currently, there is no research yet that has defined the online satisfaction on fit for children clothing in Malaysia. The main focus of this study is to explore the online apparel shopping satisfaction on sizing and fit for Malaysian children from the perspectives of parents or guardians. This study is divided into 3 objectives;

1. To identify the specific aspects of evaluations on sizing and fit that are most concerned by parents or guardians while making apparel selection.

2. To determine problems that parents or guardians encounter on sizing and fit while purchasing apparel to their children via online.

3. To identify any significant difference between genders, ages, races, residence areas and household incomes with respect to online satisfaction level items.

\section{Methodology}

Questionnaire has been developed from the focus groups discussion and references from a journal written by R. Otieno (2000). The discussion have been organized to look into the real problem faced by parents or guardians while buying children apparel via online. The discussions were focusing to a group of children aged ranging from new born to 6 years old children. A total of 143 questionnaires were gathered from 250 questionnaires that have been distributed randomly to parents or guardians from several child-care centers and pre-school around Klang Valley. Cronbach alpha has been performed to test the validity of the questionnaire. The value is 0.837 , which indicates that the reliability of the items used in the questionnaires. The study was conducted in August 2018.

Analysis of variance (ANOVA) were used to determine the effect of various parents' or guardians' demographics characteristics such as age, race, household income and residence 


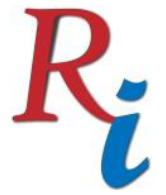

\section{Asia Proceedings of Social Sciences \\ (APSS) \\ www.readersinsight.net/APSS}

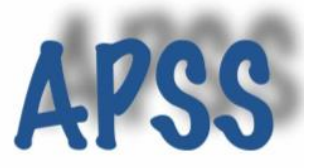

area on their children's apparel online shopping satisfaction levels. Mean of satisfaction levels among genders and residence areas were tested using T-Test.

\section{Results}

The multi-racial respondents with different genders, ages, total household income and area of residence were gathered to ensure the responses received will reflect the true result. More than half of total parents or guardians prefer shopping via online and willing to spend more for better fit apparel.

Comparison of means between demographic characteristics and children's apparel online shopping satisfaction levels have been done. It was resulted that only ANOVA has provided an evidence on mean differences occurred between online satisfaction levels among household income ( $\mathrm{p}$-values=0.021). Higher income households had greater discrepancies on satisfaction level as compared to lower income household.

Similar with Zakaria, Taib, Tan, \& Wah (2008), girth and length were used in measuring key dimensions which were height and bust for upper body and, height and waist girth for lower body.

Parents and guardians were opined that, online shopping is an easy-shopping platform but consumers take risk in purchasing because they cannot try the apparel for fitting. Fifty-eight parents or guardians were not satisfied with the apparel that they received via online purchasing. Seventy percent of them complained about unintelligible label of sizing, confusing information and variability of sizing system within and between brands.

\section{Findings}

Almost all parents or guardians said that shopping dissatisfaction on children apparel was derived from the sizing and fit problems. Majority of them willing to pay more for values.

Different sizing system among brands can lead to consumer confusion in clothing selection. The dissatisfaction will resulted retailers loss for consumers to competitors, negative viral about products and, returning will create hassle for consumers and a loss for retailers. Good quality of apparel and services from online retailers, will ensure the loyal consumers to serve their website again for purchasing. 


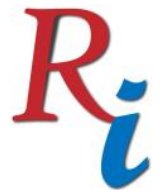

Asia Proceedings of Social Sciences

(APSS)

www.readersinsight.net/APSS

\section{Acknowledgement}

This research work is supported by the Universiti Kuala Lumpur Short Team Research Grant (str17088).

\section{References}

Norum, P. S. (1995). Consumer satisfaction with shopping experiences and clothing products in the children' s wear market, 331-347.

Otieno, R. (2000). The role of garment sizing in creation of customer satisfaction: Indications from focus group responses. Journal of Fashion Marketing and Management, 4(4), 325-335. https://doi.org/10.1108/eb022600

Wu, M.-Y., \& Tseng, L.-H. (2014). Customer Satisfaction and Loyalty in an Online Shop: An Experiential Marketing Perspective. International Journal of Business and Management, 10(1), 104-114. https://doi.org/10.5539/ijbm.v10n1p104

Zakaria, N. (2016). Clothing for Children and Teenagers, Anthropometry, Sizing and Fit. Woodhead Publishing. from https://play.google.com/books/reader?id=PiqiBQAAQBAJ\&lr=\&printsec=fro ntcover \&pg $=$ GBS.PA33\# $\mathrm{v}=$ onepage $\& \mathrm{q}=$ Clothing for Children and Teenagers\%3A Anthropometry\%2C Sizing and Fit $\& \mathrm{f}=$ falsenUiItDZfQdInrBOG81Y\&redir_esc $=y \% 23 \mathrm{v}=$ onepage $\& \mathrm{q}=$ Clothing for Children and Teen

Zakaria, N., Taib, J. S. M. N., Tan, Y. Y., \& Wah, Y. B. (2008). Using data mining technique to explore anthropometric data towards the development of sizing system. Proceedings - International Symposium on Information Technology 2008, ITSim, 2. https://doi.org/10.1109/ITSIM.2008.4631721 